\title{
Pengenalan Geografis Kawasan Lampung (Satu Kajian Ringkas)
}

W. Anwar Falah

Keywords: development, area, city, settlement, Lampung, colonial

\section{How to Cite:}

Falah, W. A. Pengenalan Geografis Kawasan Lampung (Satu Kajian Ringkas). Berkala Arkeologi, 15(3), 168-172. https://doi.org/10.30883/jba.v15i3.689

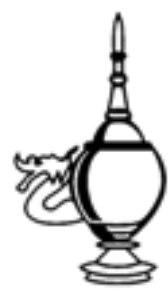

\section{Berkala Arkeologi}

https://berkalaarkeologi.kemdikbud.go.id/

Volume 15 No. 3, 1995, 168-172

DOI: $10.30883 /$ jba.v15i3.689 


\title{
PENGENALAN GEOGRAFIS KAWASAN LAMPUNG (Satu Kajian Ringkas)
}

\author{
W. Anwar Falah \\ (Balai Arkeologi Bandung)
}

\section{Pengantar}

Kajian arkeologi keruangan skala kawasan seyogyanya mensyaratkan adanya pemahaman geografis mengenai kawasan yang dikaji, baik pengertian geografis aspek lingkungan alam (natural setting) maupun aspek lingkungan kebudayaannya (cultural setting). Salah satu pendekatan yang dapat dilakukan adalah pendekatan historis/ diakronis atas geografi suatu kawasan sejak sejauh mungkin ke belakang. Pendekatan geografis secara diakronis, terutama dalam pengertian merunut perubahan lanskap serta dinamika pergerakan populasi manusia pada suatu kawasan dari masa ke masa akan sangat membantu bagi kepentingan penjelasan-penjelasan tentang perubahan-perubahan ataupun kesinambungan kebudayaan yang terjadi di kawasan itu, atas dasar pemahaman adanya hubungan fungsional timbalbalik antara lingkungan alam dan lingkungan kebudayaan manusia sebagai satu kesatuan ekologis (cf. Abruzzi 1982:13).

Pengenalan mengenai geografis kawasan Lampung dikemukakan sebagai suatu upaya kajian atas hasil penelitian besar antara ORSTOM (Perancis) dengan DEPTRANS RI (1989) yang telah melakukan penelitian studi transmigrasi di Propinsi Lampung, selain melalui kajian atas beberapa pustaka kesejarahan, arkeologi, antropologi serta dari hasil pengamatan langsung pada beberapa kesempatan penelitian arkeologi yang penulis ikuti di kawasan ini.

Karakteristik geografis yang terutama penulis soroti adalah mengenai perubahan-perubahan lanskap serta, sejalan dengan itu, mengenai pergerakan populasi manusia (migrasi) di kawasan ini dari waktu ke waktu, yang penulis batasi hing-ga periode penyelenggaraan program 'kolonisa-tie' yang diselenggarakan oleh pemerintah Hindia Belanda di awal abad ke $20 \mathrm{M}$. Pengertian Kawasan Lampung dalam konteks keluasannya, penulis batasi dalam paper ini, identik dengan pengertian wilayah administrasi Propinsi DT. I Lampung. Hanya saja penulis tidak bermaksud menyoroti secara khusus aspek-aspek yang berkaitan dengan subyek-subyek administratif dari kawasan ini. Secara terintegrasi untuk subyek-subyek geografis yang disajikan penulis juga melakukan pendekatan interpretatif, terutama dalam konteks kebudayaan, yang meliputi konteks historis, arkeologis dan antropologis dari kawasan ini.

\section{Lanskap}

Secara giobal geomorfologi kawasan Lampung, yang memiliki luas $35.376 .50 \mathrm{Km} 2$ meliputi zona-zona/sub kawasan-sub kawasan yaitu: zona /sub kawasan pesisir (coastal) yang berbatasan dengan perairan Samudera Indonesia (di sebelah barat dan barat daya kawasan). Zona ini ke aran dalam bersambungan dengan zona pegunungan Bukit Barisan yang merupakan sambungan dari arah Sumatera Barat. Kemudian zona pegunungan ini ke arah dalam bersambungan dengan zona hutan belantara; hujan (all types rainforest) yang berada pada dataran tinggi bersambungan melingkar yaitu ke arah Pakuan Ratu hingga daerah Mesuji, dan Menggala (Lampung Utara), kemudian bersambungan ke arah selatan (Lampung Tengah bagian timur), ke daerah Seputih Mataram, mencakup area hutan suaka margasatwa Way Kambas, daerah Sukadana hingga mula merenggang ke arah Kalianda (Lampung Selatan). Zona/sub kawasan pesisir lainnya adalah zona pesisir yang berbatasan dengan Selat Sunda dan Laut Jawa, yaitu mulai dari arah tenggara hingga timur laut yang sebagian besar merupakan hutan lahan basah (swamp forest) dan hutan bakau (mangrove). Di sekitar muara sungai Tulang Bawang area hutan lahan basah menembus ke pedalaman yaitu ke arah barat dan barat laut hingga ke sekitar daerah Menggala dan Mesuji. Selanjutnya yang terahir adalah zona pertanian /hutan terbuka yang sekaligus juga saat ini telah berkembang menjadi zona agro ekonomik: industri (estate) dan zona urban dengan tempattempat pusat Bandar Lampung (ibukota propinsi/Tanjung Karang dan Teluk Betung), Metro, dan Kota Bumi.

Kawasan Lampung memiliki banyak sungai, yang sebagian besar berasal dari sekitar pegunungan Bukit Barisan, serta sebagian dari sekitaran zona hutan belantara; dataran tinggi Lampung Barat dan Utara. Hal yang menarik untuk kepentingan interpretasi arkeologis dalam hubungannya dengan aliran-aliran sungai di kawasan Lampung adalah masih bisa diamatinya poia pemukiman lokal (pedesaan-pedesaan asli) di sepanjang tepian sungai-sungai di kawasan ini. Dapat ditafsirkan kiranya bahwa pola pemukiman sepanjang tepian sungai tersebut merupakan kesinambungan dari masa-masa purba yang tetap bertahan. Sekalipun tentunya dengan tingkat ke- 
padatan yang kemudian berkembang. Dari hasil penapakan (plotting) tim penelitian ORSTOMDEP.TRANS RI. dapat diamati pemukiman-pemukiman pribumi menempati, antara lain sepanjang tepian sungai-sungai Way Ranau, Way Semangka, Way Umpu, Way Besai, Way Kanan, Way Kiri, Way Sekampung. Way Seputih, Way Tulang Bawang, serta Way Mesuji. Unsur hidromorfologis lain selain sungai di kawasan Lampung adalah danau, yaitu danau Ranau dan danau Rarem, keduanya di Lampung Barat, serta klaster-klaster rawa yang terutama dominan di sekitar pesisir timur kawasan.

Kawasan Lampung memiliki iklim dengan curah hujan yang bervariasi. Zona pegunungan Bukit Barisan, termasuk daerah pesisirnya serta beberapa area penyangga di zona hutan sebelah timur pegunungan ini, memiliki curah hujan yang berkisar antara 3000 s.d. $4000 \mathrm{~mm}$ per tahun. Sedangkan risiko kemaraunya terhitung pendek. Zona hutan belantara, khususnya pada area sebelah timur pegunungan Bukit Barisan serta area sekitar Pakuan Ratu dan Mesuji memiliki curah hujan berkisar antara 2500 s.d. 3000 mm per tahun, tertinggi pada bulan-bulan Oktober hingga April dengan risiko kemarau kurang dari dua bulan per tahun. Zona pertanian/hutan terbuka hingga ke area-area perkotaan serta zona hutan iahan basah memiliki curah hujan berkisar anta-ra 1500 s.d. $3000 \mathrm{~mm}$ per tahun, tertinggi pada bulan-bulan Desember-Januari, dengan risiko kemarau rata-rata separuh tahun, berlangsung pada bulan-bulan Juni s.d. Oktober.

Bagian terbesar kawasan Lampung dilapisi oleh dua tipe jenis tanah yaitu jenis latosol dan podzolik merah-kuning. Tanah podzolik merahkuning diketahui sebagai jenis tanah yang kurang subur, yang terbangun dari berbagai tipe asam geologis, yang tidak dapat digarap / dikultifasi secara terus menerus, terutama melalui media teknologi pertanian tradisional karena memiliki kapasitas pertukaran rendah, serta miskin unsur-unsur organik. Tipe podzolik merah-kuning sebarannya meliputi sebagian dari zona pesisir (Lampung Barat), serta di sebagian besar wilayah Lampung Tengah hingga ke Lampung Utara. Tipe tanah ini diketahui tidak baik untuk tanaman pertanian/perkebunan, kecuali untuk karet. Sebaliknya, tipe tanah jenis Latosol diketahui memiliki kandungan unsur-unsur nutrisi serta unsur-unsur organik yang kaya, layak untuk berbagai jenis tanaman pertanian/perkebunan, terutama jika memperoleh suplai air yang banyak. Tipe latosol sebarannya meliputi $30.7 \%$ dari luas kawasan. yaitu di sekitar zona pegunungan Bukit Barisan dan zona hutan belantara Lampung Utara bagian barat. Lampung Barat hingga ke bagian zona pe- sisir dan zona hutan belantara Lampung Selatan. Zona-zona tersebut diketahui memiliki kuantitas curah hujan yang tinggi setiap tahunnya. Tipe tanah lainnya yang termasuk cukup luas area penyebarannya adalah jenis tanah aluvial hidromorfik yang mela-pisi zona pesisir timur (zona hutan lahan basah). Jenis tanah ini memiliki kesuburan yang cukup baik (Levang, 1989:195; fig. 3.2.).

Karakteristik komponen-komponen air dan tanah kawasan Lampung menentukan pola-pola sistem produksi di kawasan ini. Ada tiga kategori sistem produksi utama dalam pola pertanian di Kawasan Lampung yaitu, kebun/ladang, sawah dan tegal. Jenis kebun atau ladang kiranya merupakan hasil perkembangan yang logis dan evolusi sistem penggarapan lahan pertanian kultivasi tebang bakar (slash and burn cultivation) (Levang, ibid:201). Selaras dengan karakteristik tanah serta iklim di kawasan Lampung sistem produksi pertanian ini didukung di lingkungan komunitas-komunitas lokal yang berada di sekitar zona hutan belantara dan di sekitar lembah-iembah kaki zona pegunungan Bukit Barisan, yang bertanah subur serta memiliki air yang cukup. Secara diakronis sistem kebun yang pada mula. nya mengutamakan produksi padi ladang seba-gai kebutuhan interen komunitas (self sufficient) serta damar, pada masa-masa kemudian, kemungkinan sejak masa kejayaan Sriwijaya (cf Wolters,1967:67), atau paling sedikit telah berkembang pada masa kejayaan kesultanan Banten, dikembangkan menjadi media pertanian komersial dengan penanaman lada sebagai komoditi perdagangan serta kemudian cengkeh, kopi, tebu, yang mulai dikembangkan pada masa Hindia Belanda di awal abad ke 20, serta masih berlanjut hingga saat ini. Area-area perkebunan tertua di kawasan Lampung antara lain di sekitar dataran tinggi Sukadana, daerah-daerah sebelah barat Kotabumi serta di wilayah Kasui (Lampung baratlaut) (Levang, loc.cit:20).

Sistem produksi pertanian sawah, yang sangat mengandalkan irigasi sesungguhnya bukan merupakan teknologi pertanian tradisional yang bersifat lokal (indigenous) bagi kawasan Lampung. Sistern ini dibawa dan diselenggarakan di kawasan ini oleh para transmigan asal Jawa mulai tahun 1905 sejalan dengan program transmigrasi (kolonisatie) yang di jalankan pemerintah Hindia Belanda. Sekalipun sejak masa sebelumnya pesawahan permanen memang telah ada di daerah-daerah pesisir Lampung Selatan-Tengah yang diselenggarakan oleh para imigran asal Banten. Hingga masa Perang Dunia II. pemerintah Hindia Belanda menempatkan lebih dari 90.000 transmigran asal Jawa di tiga area 
yang telah dipersiapkan dengan sarana irigasi, yaitu, Gading Rejo-Pringsewu (Lampung Selatan)

Wonosobo, dan Trimurjo-Metro (Lam-pung Tengah) (Levang, ibid:223). Hingga saat ini areaarea inilah yang merupakan area-area pesawahan terpadat di kawasan Lampung. Se-mentara Metro saat ini telah berkembang men-jadi sebuah kota baru dan menjadi ibukota Kabupaten Lampung Tengah.

Sistem produksi pertanian jenis tegal atau tegalan pada dasarnya adalah pola penggarapan lahan kering, pada area-area dataran tinggi, yang dimanfaatkan sebagai penghasil tanaman panen (food crops) periodik, seperti jagung, ketela, kacang-kedelai. Seperti halnya sawah, sistem produksi pertanian jenis tegalan juga dikembangkan oleh transmigran asal Jawa di awal abad $20 \mathrm{M}$ (Levang, ibid:243).

\section{Pergerakan Populasi Manusia \\ A. Orang Pubian}

Sekalipun masih memerlukan penelitian yang lebih mendalam, penduduk asli (tertua) kawasan Lampung adalah yang dikenal sebagai kelompok etnik Orang Pubian (cf.Sevin, 1989:51). Hingga pertengahan abad ke $19 \mathrm{M}$ kelompok etnik ini menempati area di antara Padang Ratu, Kota Agung (hingga pesisir timur Teluk Semangka), Teluk Betung (hingga pesisir timur Teluk Lampung) serta wilayah selatan Gunung Sugih, di mana area ini dibelah oleh sungai Way Sekampung (Sevin,ibid:Fig.1.4). Dalam konteks arkeologi, kuat kemungkinannya Orang Pubian adalah keturunan langsung dari para pendiri bangunan-bangunan megalitik yang banyak dijumpai di kawasan ini, yang tergolong keturunan dari ras Melayu awal (Malayid;3000-1000 tahun yil.) (cf. Yacob, 1992:156-157).

\section{B. Gelombang Sekalabrak}

Sekalabrak, adalah penamaan lokal untuk satu wilayah di sekitar Danau Ranau yang secara tradisi diketahui di masa lampau (abad 14-15 hingga $18 \mathrm{M}$ ) merupakan pusat gerakan migrasi ke kawasan Lampung. Wilayah Sekalabrak saat ini termasuk ke dalam bagian tiga propinsi; yaitu Bengkulu, Sumatera Selatan, serta Lampung. Diperkirakan di awal abad ke 14 M, wilayah Sekalabrak, khususnya daerah Belalau (sebelah selatan Danau Ranau) merupakan daerah dengan tekanan populasi yang tinggi. Keadaan itu pula yang diperkirakan menjadi faktor penyebab terjadinya gerakan migrasi dari daerah ini khususnya, serta dari wilayah Sekalabrak umumnya ke bagian tengah serta pesisir barat dan selatan kawasan Lampung (Sevin, loc.cit:49). Namun demikian, dalam kaitan lada dan juga cengkeh, ser- ta kemudian kopi, yang berkembang dewasa itu sebagai komoditi perdagangan, yang mana perkembangannya itu dipacu oleh kekuatan poli-tik ekonomi sejak masa kerajaan Srivijaya, serta kemudian oleh kesultanan Banten dan Palembang (cf. Wolters, loc.cit:67; Tjandrasasmita, 1977:29,30), kiranya menjadi penggerak kuat terjadinya migrasi yang berlanjut ke kawasan Lampung, yaitu dalam rangka ekspansi lahan perkebunan.

Daerah Belalau berdekatan dengan daerah Sumberjaya; yang merupakan penamaan daerah baru sejak dibukanya daerah ini sebagai daerah transmigrasi paska kemerdekaan RI [program Biro Rekonstruksi Nasional (1951)J, yang saat ini termasuk ke dalam wilayah administrasi Kabupaten Lampung Barat. Di daerah ini banyak sekali ditemukan situs-situs megalitik di antaranya yang menonjol serta telah dipugar adalah situs megalitik (kompleks menhir dan dolmen) Batu Berak, dan kuat kemungkinannya situs-situs baru akan ditemukan lagi. Dalam tahun 1994 yang lalu tim penelitian dari Balai Arkeologi Bandung pada kesempatan penelitian di situs megalitik Batu Berak, menemukan beberapa situs megalitik tidak berjauhan dengan situs Batu Berak yang belum pemah dilaporkan sebelumnya. Dengan demikian kuat kemungkinannya situs-situs megalitik di daerah Sumber Jaya merupakan tinggalan dari populasi manusia daerah Belalau dari masanya.

Kelompok-kelompok etnik lainnya, yang saat ini telah dianggap sebagai kelompok etnik pribumi Lampung, adalah yang dikenal sebagai Orang Abung dan Orang Pesisir. Kedua kelompok etnik ini melakukan migrasi dari wilayah Sekalabrak ke daerah-daerah tengah dan pesisir terutama pesisir barat, selatan, serta tenggara, kawasan Lampung. Orang Abung mulai melakukan migrasi di sekitar pertengahan abad $15 \mathrm{M}$ serta berlanjut hingga ahir abad ke $18 \mathrm{M}$. Orang Abung saat ini terutama secara wisesa menempati area di daerah Lampung Tengah. Sedangkan Orang Pesisir, melakukan migrasi dari wilayah Sekalabrak beberapa waktu kemudian setelah Orang Abung. Mereka bergerak ke arah selatan hingga barat daya, kemudian bersinambungan hingga saat ini menempati area sepanjang pesisir Lautan Hindia, dengan kon-sentrasikonsentrasi di sekitar Kuripan, Kru'i, Teluk Semangka, Telụk Lampung, serta Kalianda (Sevin, ibid:51;fig.1.3). Perlu dipahami bahwa penyebutan nama kelompok etnik Orang Pesisir berlaku setelah mereka migrasi serta kemudian mukim di area-area pesisir kawasan Lampung. 


\section{Gelombang Banten}

Orang Pubian, Orang Abung, dan Orang Pesisir menjadi akar atau dasar dari perkembangan populasi manusia lokal;pribumi di masamasa kemudian; yang dalam perkembangannya tidak terhindar dari peristiwa-peristiwa kontak budaya ataupun percampuran biologis dengan populasi-populasi manusia yang berasal dari luar kawasan Lampung. Pada perkembangannya percampuran biologis serta budaya itu melahirkan kelompok-kelompok etnik baru

Simbiosa antara Orang Pubian, Orang Abung, Orang Pesisir, Orang Sunda dan Orang Jawa yang datang ke Banten sekitar abad ke 17 $M$, serta Orang Bugis, melahirkan dua kelompok etnik baru, yaitu Orang Melinting dan Orang Meninting. Simbiosa itu terekam pula dalam legenda yang menceritakan bahwa Sultan Banten (?) pada kesempatan kunjungan ke Lampung mempunyai dua anak laki-laki dari dua wanita Lampung, yaitu dari Ratu Melinting dan Ratu Darah Putih. Kedua anak seayah itu kemudian secara tradisi dianggap sebagai nenek moyang dari Orang Melinting (melalui Ratu Melinting) dan Orang Meninting (melalui Ratu Darah Putih). Selanjutnya legenda itu juga menceritakan bah-wa keturunan dari Sultan Banten itu kemudian memperoleh hak atas kuala Sekampung dari Sultan Banten. Pusat pemukiman Orang Melinting dewasa ini menempati area di sekitar Maringgai, sehingga awam lajim pula menyebut mereka sebagai Orang Maringgai. Sedangkan Orang Meninting menempati area di sekitar Kalianda (cf.Sevin, ibid.:63).

\section{Gelombang Palembang}

Di sekitar abad ke $17 \mathrm{M}$ sungai Way Tulang Bawang, yang mengalir di bagian utara ke arah pesisir timur laut kawasan Lampung, telah menjadi jalur ekspor lada dari pedalaman. Sejarah lokal mengisahkan bahwa sejak masa yang lebih ke belakang sungai ini telah biasa dilayari oleh saudagar-saudagar (lada) dari Palembang, para bajak laut Melayu serta Orang-orang Bugis. Pangkal dari sungai ini adalah muara dari dua buah sungai di daerah Tulang Bawang, yaitu Way Kiri dan Way Kanan. Di masa-masa kesultanan Banten dan Palembang daerah Tulang Bawang dan juga Menggala dapat disebut sebagai daerah transisi kekuasaan politik dari kedua kesultanan itu. Sekitaran sungai Way Kin pada masa itu merupakan bagi-an terpinggir wilayah otoritas politik Kesultanan Banten yang dimukimi oleh keturunan Pubian dan Banten (Sunda; Jawa), yang kemudian lebih lajim disebut Orang Tulang Bawang:Orang Menggala. Sedangkan sekitaran sungai Way Kanan dihuni oleh keturunan
Komering dan merupakan bagian terpinggir dari kekuasaan Kesultanan Palembang. Dengan demikian dapat dipahami, bahwa Orang Komering (Orang Way Kanan) merupakan imigran pertama dan kawasan Palembang yang migrasi ke kawasan Lampung. Gerakan migrasi ini kiranya merupa-kan bagian dari ekspansi politik Kesultanan Palembang ke kawasan ini di sekitar akhir abad ke $17 \mathrm{M}$; yang sebelumnya lebih dikuasai oleh Kesultanan Banten (cf. Sevin, ibid.: 63-69).

Migrasi Orang Komering sebagaimana yang diuraikan di atas, dapat dikatakan meru-pakan pangkal dari rangkaian sejarah migrasi manusia dari kawasan Palembang ke kawasan Lampung. terutama ke bagian utara (Orang Ogan), barat (Orang Sumendo) dan timur laut (Orang Mesuji) kawasan, yang terus bersinam-bungan serta seiring pula dengan gerakan-ge-rakan migrasi dari kawasan lainnya (Bagian lain dari Pulau Sumatra,Pulau Jawa, Bali, Sulawesi). Motif gerakan-gerakan migrasi ini kiranya juga dapat dipahami sebagai dampak atau konse-kuensi logis dari kebijakan politik ekonomi Ke-sultanan Palembang, yang juga kemudian diam-bil alih oleh V.O.C (1737 M), Inggris (Raf-fies;1817-1819 M) serta Hindia Belanda hingga masa Perang Dunia II, sehubungan dengan potensi agroekonomi kawasan ini.

\section{E. 'Kolonisatie'}

Secara umum kehidupan sosial di Pulau Jawa di akhir abad ke $19 \mathrm{M}$ mengalami kondisi buruk (catastrophe), yang ditandai oleh terjadinya krisis kesejahteraan ekonomi pada derajat yang sangat parah di satu pihak dan peledakan penduduk di lain pihak, terutama di daerah Jawa Tengah. Konon keadaan ini merupakan dampak dari kegagalan program 'cultuur stelsel'nya van den Bosch yang mengalami antiklimaks di pertengahan abad ke $19 \mathrm{M}$ (Sevin, ibid :75). Di latar belakangi oleh kondisi itu, di awal abad ke 20 M pemerintah Hindia Belanda menyelenggarakan program yang disebut 'kolonisatie' di kawasan Lampung. 'Kolonisatie'; kolonisasi di kawasan Lampung pada pokoknya adalah bentuk kebi. jakan transmigrasi, dalam konteks mengurangi peledakan populasi manusia dengan cara memindahkan (resettlement) penduduk, terutama dari daerah Jawa Tengah, dengan arahan kebijakan membuka lahan-lahan primer/perawan untuk dijadikan lahan-lahan pertanian sebagai solusi untuk meningkatkan perekonomian, terutama bagi para transmigran itu sendiri (cf ORSTOM-DEP-TRANS RI, 1989:Glossary: Sevin loc.cit.:83). 
Planologi sistem peruntukan lahan, khususnya pertanian, dari program kolonisasi di kawasan Lampung yang dimulai sejak tahun 1905 $M$, pada pokoknya menerapkan sistem yang sama dengan yang telah diterapkan di Pulau Ja-wa, yaitu menyelenggarakan sistem pertanian sawah irigasi (irrigated rice farming) yang pada prakteknya diselenggarakan sendiri oleh para transmigran. Pemerintah Hindia Belanda dalam hal ini menyelenggarakan pemba-ngunan irigasiirigasi teknis. Sebagaimana telah diterangkan bahwa hingga era P.D. II (1942) Pemerintah Hindia Belanda berhasil memindahkan lebih dari 90.000 transmigran asal Jawa, yang di distribusikan di tiga wilayah beririgasi, yaitu di Gading Rejo-Pringsewu, Wonosobo, dan Trimurjo-Metro (Levang, 1989:223).

\section{Penutup}

Melalui kajian ringkas yang telah penulis uraikan, kiranya dapat diambil beberapa butir temuan yang kiranya dapat di jadikan pelengkap dasar-dasar hipotesis, dalam rangka studi arkeologi keruangan kawasan Lampung, yaitu :

1) Bahwa kebijakan-kebijakan pemindahan penduduk serta pengembangan agro industri, yang dirintis sejak masa Hindia Belanda adalah yang paling bertanggung jawab atas terjadinya perubahan-perubahan lanskap di kawasan ini;

2) Bahwa sejak awalnya Kawasan Lampung merupakan kawasan tujuan migrasi konservatif, yaitu migrasi akibat tekanan penduduk yang tinggi (over populated) di tempat asal;

3) Bahwa Kawasan Lampung dari masa ke masa merupakan kawasan penyangga sumber daya ekonomi kekuatan-kekuatan politik di sekitarnya (Sriwijaya, Banten, Palembang. Kolonial Inggris dan Belanda); serta tanpa ada bukti-bukti pernah menjadi tempat pusat kekuatan politik yang mandiri;

4) Bahwa peninggalan-peninggalan arkeologi bercorak Islam (pengaruh Banten; Palembang) lebih mungkin banyak dijumpai di kawasan ini daripada peninggalan arkeologi bercorak Hindu-Buddha;

5) Bahwa justru tradisi megalitik pernah berkembang serta berlanjut hingga menjelang masa Islamisasi di kawasan ini; yang didukung oleh Orang Pubian, Orang Abung serta Orang Pesisir ('asosiasi Sekalabrak');

6) Bahwa kuadran barat laut dan barat daya kawasan Lampung merupakan area-area hunian manusia paling tua dari kawasan itu. yang kemungkinan telah dihuni sejak jaman prasejarah;

\section{KEPUSTAKAAN}

Abruzzi, William S.,1982. Ecological Theory Ethnic Differentiafion among Human Populations, dalam Current Anthropology, Vol. 23 No. 1, The University Of Chicago Press.

Harris, Marvin. 1983. Cultural Anthropology, Harper \& Row, New York.

Jacob, Teuku., 1992. Manusia Malayu Kuno, dalam Seminar Sejarah Malayu Kuno, Pemda Tkt.I Jambi.

Levang, Patrice. 1989. Farming Systems and Household Incomes dalam Transmigration, ORSTOM-DEPTRANS RI

Sevin, Olivier. 1989. History and Populations dalam Transmigration ORSTOM-DEP. TRANS RI.

Tjandrasasmita,Uka,(ed.).,1977. Sejarah Nasional Indonesia, Jilid III. Balai Pustaka, Jakarta.

Wolters, O.W.,1967. Early Indonesian Commerce, Cornell University Press, Ithaca, New York. 